\title{
Skleritler ve üveitler
}

\section{Scleritis and uveitis}

\author{
Suzan Güven Yılmaz@
}

Ege Üniversitesi Tıp Fakültesi, Göz Hastalıkları Anabilim Dalı, İzmir, Türkiye

\section{Öz}

Sklerit ve üveitler akut kırmızı göze neden olan, görme kaybı potansiyeli taşıyan gözün nadir görülen inflamatuar hastalıklarındandır. Kırmızı göz tanısında görmeyi tehdit edici hastalıkların benign durumlardan ayırımı önemlidir. Bu makalede sklerit ve üveitin belirtileri, klinik özellikleri ve ayırıcı tanısı tartışılmıştır.

Anahtar Sözcükler: Akut kırmızı göz, sklerit, üveit.

\begin{abstract}
Scleritis and uveitis are an uncommon potentially sight threatening ocular inflammatory diseases that lead to acute red eye. It is important to distinguish sight-threatening diseases from benign conditions in red eye diagnosis. The signs, clinical features and differential diagnosis of scleritis and uveitis are discussed in this article.
\end{abstract}

Keywords: Acute red eye, scleritis, uveitis.

\section{Giriş}

İnflamatuar göz hastalıkları arasında yer alan sklerit ve üveitler, tedavi edilmediği taktirde ciddi görme kaybı ile sonuçlanacak komplikasyonlara yol açabilen, ağrılı kırmızı gözün başlıca nedenleri arasında yer almaktadırlar. Sıklıkla idiyopatik, otoimmün ve nadiren infeksiyöz kaynaklı olarak gelişmektedirler. Prognoz ve tedavilerinin farklı olması nedeni ile konjonktivit, episklerit, kuru göz ve keratit gibi kırmızı göze neden olan diğer hastalıklardan ayırıcı tanılarının yapılması büyük önem taşımaktadır $(1,2)$.

Üveit ve skleritler etkilenen anatomik yapılar nedeni ile birbirinden keskin sınırlar ile ayrılan iki farklı hastalık grubunu oluştursalar da, ortak patogenetik süreci paylaşmaları sebebiyle altta yatan sistemik patolojiler ve tedavi modaliteleri iki hastalıkta da büyük benzerlikler göstermektedir. Ayrıca, skleritlerin hastalık seyrinde inflamasyonun skleradan üveal trakta yayılması ile \%42 oranında üveite neden olabilecekleri bildirilmiştir (3).

\section{Skleritler}

Sklera, göz küresinin dış 4/5'ini kaplayan dokudur. Önde kornea, arkada optik sinir ile birleşim göstermektedir. Episklera, skleral stroma ve lamina fuska olmak üzere başlıca üç tabakadan oluşmaktadır. Episklera yoğun vasküler bağ dokusundan oluşur ve inflamasyonu episklerit olarak adlandırılmaktadır $(4,5)$.

\section{Episkleritler}

Episklerit sık görülen, benign, idiyopatik, rekküren bir hastalıktır. Hastaların \%50'sinde neden idiyopatik iken, üçte birinde skleritte olduğu gibi altta sistemik hastalık yatmaktadır (2). Hafif ve tekrarlamayan formlarda araştırmaya gerek yoktur. Basit ve nodüler olmak üzere iki tipte görülmektedir $(2,4,5)$.

\footnotetext{
Sorumlu yazar: Suzan Güven Yılmaz

Ege Üniversitesi Tıp Fakültesi, Göz Hastalıkları Anabilim Dalı, İzmir, Türkiye

E-posta:drsuzan2003@yahoo.com
} 


\section{Semptom ve Klinik Bulgular:}

Basit episklerit olguların 3/4'nü oluştur ve semptom kızarıklık ve hafif rahatsızlık hissidir. Diffüz veya sektoriyel hiperemi mevcuttur (Şekil1A) $(2,4,5)$. Episkleritte kızarıklık konjonktival ve superfesiyal damarlardan kaynaklandığı için pamuk aplikatör ile inflame damarları sklera üzerinden kaydırmak ve \%2,5 epinefrin ile soldurmak mümkündür (2). Nodüler sklerit, basit tipe göre daha akut başlangıçlı ve daha uzun sürme eğilimindedir. Sabah uyanınca hasta gözündeki kızarıklığı fark etmekte, 2-3 günde kızarıklık bölgesi boyut olarak büyür ve daha rahatsız edici hale gelmektedir (Şekil-1B) $(4,5)$.

\section{Tedavi:}

Hafif olgular ilaçsız takip önerilirken, semptomatik olgular suni gözyaşı ve steroidli damlaların yanı sıra sistemik NSAil ilaçlar ile tedavi edilmelidir (2, $4,5)$.

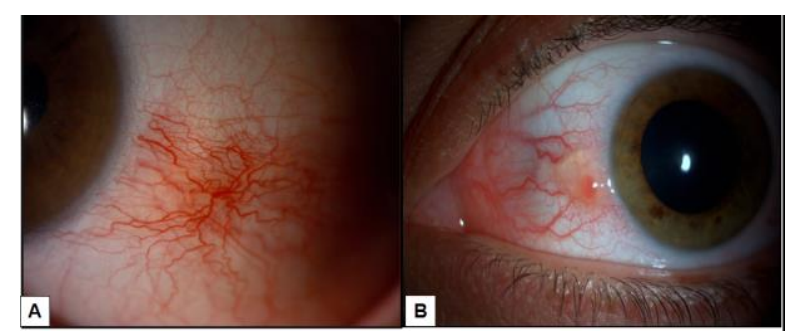

Şekil-1. Episkleritli Olgulara Ait Ön Segment Fotoğrafları

A) Episklerit nedeniyle takipli bir olgunun ön segment fotoğrafında dilate konjonktival ve yüzeyel episkleral damarlara ait sektöriyel hiperemi görünmektedir. B) Nodüler episkleritli başka bir olguda limbus komşuluğunda inflamatuar nodül ve nodül çevresinde dilate konjonktival, yüzeyel episkleral damarlar izlenmektedir (Kornea Birimi arşivinden).

\section{Ayırıcı Tanı:}

Sklerit başta olmak üzere, konjonktivit, keratit gibi kırmızı göz yapanlar diğer nedenler. Tablo-1'de episklerit ve skleritlerin ayırıcı tanısında göz önünde bulundurulması gereken özellikler verilmiştir.

Tablo-1. Episklerit ve skleritlerin karakteristik özellikleri.

\begin{tabular}{ccc}
\hline Özellikler & Episklerit & Sklerit \\
\hline Anatomi & Episklera & Sklera \\
Yaş (yıl) & $20-40$ & $20-60$ \\
Cinsiyet & Kadınlarda daha sık & Kadınlarda daha sık \\
Klinik özellikler & Hafif ağrı, geçici & Ağrılı \\
Altta yatan sistemik hastalık & Nadiren & Sıklıkla \\
Komplikasyonlar & Nadir & Sık \\
Tedavi & Gerekli olmayabilir & Gerekli \\
Prognoz & Mükemmel & Değişken \\
\hline
\end{tabular}

Tablo-2. Tarafından önerilen sklerit sınıflaması.

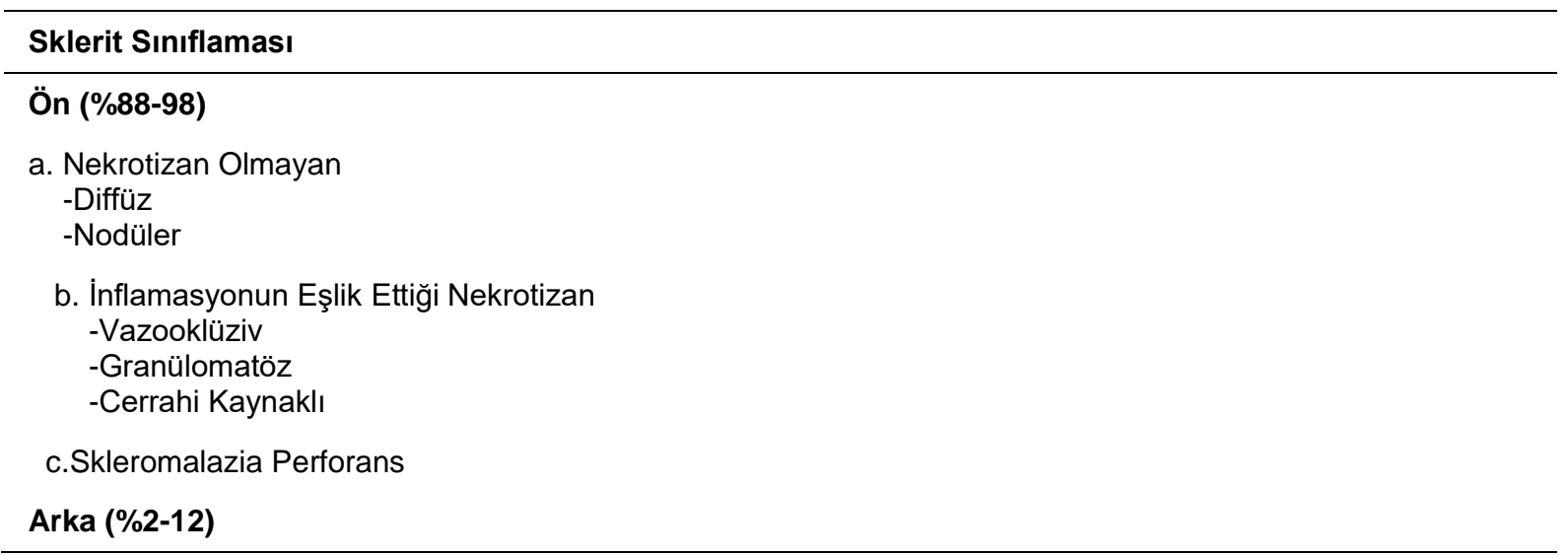




\section{Skleritler}

Tüm skleral katlar boyunca inflamatuar hücre infiltrasyonu ve ödem ile karakterize görme kaybı potansiyeli olan bir hastalıktır. Episkleritten daha nadir olarak görülmektedirler. Ciddiyeti, kendi kendini sınırlayan ataktan, komşu dokulara yayılan ve görmeyi tehdit eden nekrotizan hastalığa kadar değişkenlik göstermektedir. Genellikle kadınlarda ve en sık 4.-6. dekkatta görülür. Olguların \%32-57'sinde altta yatan sistemik bir hastalık mevcuttur $(2,5,6)$.

Hastalığın sınıflaması ilk kez Watson ve Hayreh tarafından 1976 yılında yapılmıştır (7). Bu sınıflama hastalığın ciddiyeti, prognozu ve tedavi planlaması açısından faydalıdır. Hastaların sadece \%10'unda daha agresif hastalığa ilerleyiş olmaktadır (Tablo-2) $(4,6)$.

İmmünopatogenez skleritin nedenine ve tipine bağlıdır. Otoimmun skleritlerin damarlarda immün-kompleks birikimine, idiyopatik skleritin ise makrofaj ve lenfosit infiltrasyonu ile birlikte geçirilmiş hipersensitiviteye ikincil geliştiği düşünülmektedir $(4,5)$.

\section{Semptom ve Klinik Bulgular:}

Skleritlerin karakteristik klinik bulgusu ağrıdır. Skleromalazia perforansta ağrı olmayabilir. Ağrı subakut başlangıçlı olup analjeziklere dirençli, kulak, yüz, baş ve çene bölgesine yansıyan özelliktedir. Ayrıca göz hareketleri ile artış gösterir, geceleri hastayı uykudan uyandıracak kadar yoğun bir şekilde hissedilebilmektedir. Ağrının nedeni, inflamatuar mediatör ve nekroza ikincil duyusal sinir liflerinde oluşan inflamasyon ve gerilmedir. Bu nedenle ağrı aktif skleral inflamasyonun göstergesidir. Bazen ağrı, iris sfinkter spazmına ikincil miyozise ve geçici miyopiye neden olabilmektedir (4-6).

Hemen hemen her sklerit olgusunda bulunan bir diğer bulgu mavimsi-kırmızı veya morumsu renkte derin hiperemidir. Tek bir alana lokalize veya diffüz olabilmektedir. Tekrarlayan skleritlerde sklera incelip saydamlaşabilir ve koroid pigmentlerini yansıtan mavimsi gri bir renk alabilir $(5,6)$.

Skleritlerde inflamasyon kontrol altına alınmadığı takdirde keratit, üveit, katarakt, eksudatif retina dekolmanı, makula ödemi, hipotoni ve perforasyon ile görme kaybedilebilmektedir.

\section{Ön Skleritler}

\section{a. Nekrotizan Olmayan Ön Sklerit}

Diffüz ve nodüler olmak üzere iki formda görülmektedir.
- Diffüz ön sklerit, skleritlerin en iyi huylu tipidir. Olguların \%30'unda altta yatan bağ dokusu hastalığı vardır. İnflame damarlar skleraya yapışıktır, pamuk uçlu aplikatör ile kaydırılmaz (Şekil-2A). Altta yatan hastalık tedavi edilmedikçe rekürrensler sıktır. Uzun dönem görme prognozu çok iyidir $(2,4,6)$.

- Nodüler sklerit, nodüler episklerite benzer ancak skleradan kaynaklanan nodül pamuk aplikatör ile hareket ettirilemez. Yüzde 2,5'lik fenilefrin damlası vazokonstrüksiyon yaparak konjonktival ve yüzeyel episkleral damarları soldurur ancak inflamasyona katılan derin pleksustaki vasküler yapılar etkilenmediği için hiperemi sebat edecektir (Şekil-2B) $(4,6)$.

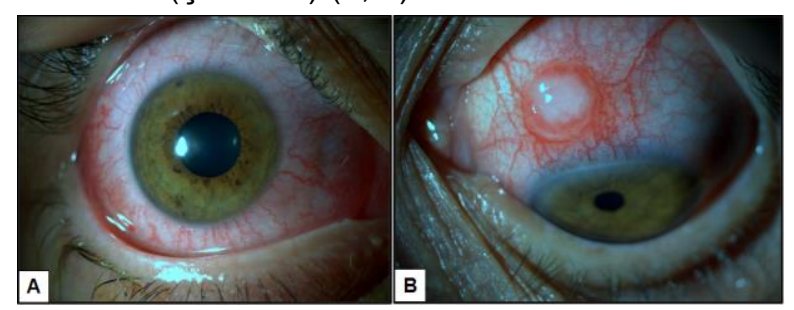

Şekil-2. Ön sklerite ait ön segment fotoğrafları.

A) Diffüz ön skleritli bir olgunun ön segment fotoğrafında her kadranda dilate konjonktival, yüzeyel ve derin episkleral damarlara ait diffüz hiperemi. B) Ön nodüler sklerit nedeniyle takipli bir olguda üst bulbar alanda inflame nodül ve nodül çevresinde dilate konjonktival, yüzeyel ve derin episkleral damarlar (Kornea Birimi arşivinden).

\section{b. Inflamasyonlu Ön Nekrotizan Sklerit}

Skleritin en agresif formudur. Çoğunlukla bilateral tutulum göstermektedir. Başlangıç yaşı biraz daha geç olup olgular genellikle 60 yaş ve üzerindedir. Erken evrede tedavi edilmediği takdirde $\% 40$ olguda görme kaybı gelişmektedir. Sistemik vaskülit nedeniyle 5 yıllık mortalite oranı \%29 olarak bildirilmiştir. İnflamasyonlu ön nekrotizan skleritler vazooklüziv, granülomatöz veya cerrahi nedenli olarak gelişebilmektedirler (4).

- Vazooklüziv tip genelde RA ile ilişkilidir. Nonperfüze episklera ve konjonktiva nedeniyle üzerleri çıplak olan ödemli skleral bölgeler mevcuttur. Bu bölgeler, birleşerek hızlı bir şekilde progresif skleral nekroza yol açmaktadırlar (Şekil3A) (4).

- Granülomatöz tip genellikle granülomatozisli polanjitis veya poliarteritis nodoza ile ilişkilidir. Hasatlık tipik olarak limbus komşuluğunda injeksiyon ile başlar ve sonra arkaya doğru yayılım göstermektedir. Sklera, episklera, konjonktiva ve komşu kornea ödemlenerek 24 
saat içinde inflamasyona katılmaktadır (Şekil-3B) (4).

- Cerrahi nedenli sklerit, sıklıkla mitomicin C ile pterjiyum cerrahisi sonucu görülmektedir (4).

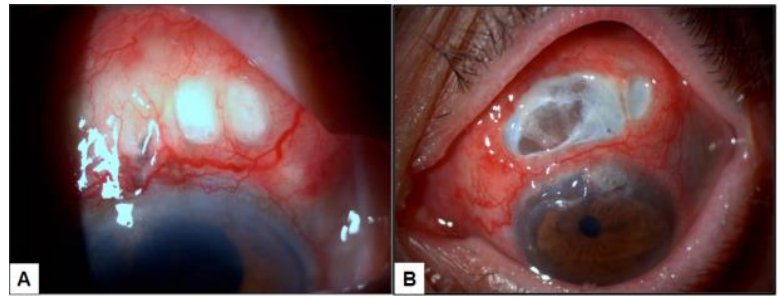

Şekil-3. İnflamasyonlu ön nekrotizan sklerite ait ön segment fotoğrafları.

A) Üst bulbar alanda nekrotik konjonktiva ve episklera nedeniyle üzeri çıplak skleral bölgeler izlenmektedir. B) Üst limbus (korneoskleral bileşke) gerisinde tam kat konjontival ve skleral nekroz nedeniyle kahverengi renkte uveal doku görünür hale gelmiştir. İnflamasyona limbus komşuluğındaki kornea da katılmış olup periferik korneal incelme dikkat çekmektedir (Kornea Birimi arşivinden).

\section{c. Skleromalazia Perforans}

Derin episkleral vasküler ağın obliteratif arteriti sonucu gelişen nekrtotizan ön skleritin nadir görülen bir formudur. İnflamasyon yoktur. Uzun yıllar boyunca RA'i olan yaşlı kadınlarda görülmektedir (Şekil-4A) (2, 4). Globun tam perforasyonu nadirdir. Glob bütünlüğü ince ancak tam fibröz tabaka tarafından sağlanmaktadır (Şekil-4B). Spontan perforasyon nadirdir, ancak darbelere göz son derece hassastır (4-6).

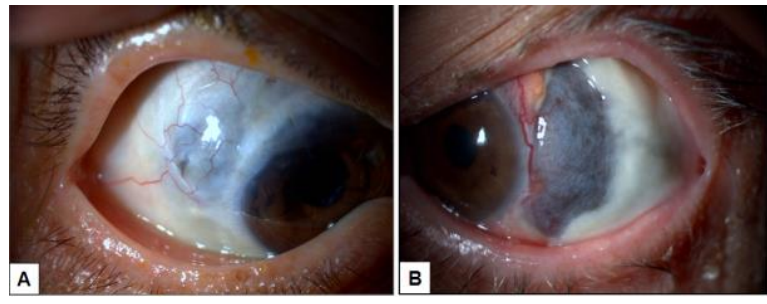

Şekil-4. Skleromalazia perforansa ait ön segment fotoğrafları.

A) Üst temporal bölgede bağlı incelmiş skleral alan. B) Temporal yarıda ileri derecede incelmiş skleral duvar nedeniyle uvea dokusunun öne protrüzyonu izlenmektedir. (Kornea Birimi arşivinden).

\section{Arka Skleritler}

Arka sklerit ora serratanın arkasındaki skleranın inflamasyonudur $(4,8)$. Bu neden ile tanı için arka segment muayenesi önem kazanmaktadır. Fundus bakısında retinal ve koroidal foldlar, eksüdatif retina dekolmanı ve koroidal katlantılar izlenebilmektedir. B-mod USG'de diffüz ya da nodüler skleral kalınlaşma ve özellikle "T işareti"
(Tenon boşluğunda ve optik disk kılıfında sıvı) tanı koydurucudur $(9,10)$.

Posterior sklerit çoğunlukla idiyopatiktir. Olguların \%30-40'ında sistemik bir hastalık (RA, JiA, tekrarlayan polikondritler, granülomatozisli polianjitis, PAN, SLE, AS, UK, Chron Hastalığı, Reiter Sendromu, sarkoidoz) birliktelik mevcuttur. İnfeksiyöz etiyoloji (lyme, bartonella, sifiliz, tüberkülöz, herpes zoster, acantomoeba) \%10'dan azdır (5, 8, 9). Kırk yaş üstü ve kadınlarda daha sık görülür. Olguların \%35'inde hastalık bilateraldir $(4,5,8)$.

Tedavi:

Topikal ve sistemik steroidler, immünsüpresif ilaçlar (MTX, mikofenolat mofetil, azatiopirin, sandimmun, siklofosfamid) ve biyolojik ajanlar (rituximab) kullanılmaktadır (4-6).

\section{II. Üveitler}

Üveitler; iris, siliyer cisim ve koroidden oluşan üveal sistemin inflamasyonu ile karakterize, görmeyi tehdit edici geniş bir hastalık grubunu oluşturmaktadır. Yakın komşulukları nedeniyle çoğunlukla inflamasyona retina, vireus, optik sinir gibi intraoküler yapılar da katılmaktadır. Üveitler, nadir görülmelerine karşın (insidans 52/100 000), körlüklerin \%10-15'inden sorumlu olup, genç-orta yaş aralığındaki çalışan popülasyonu etkilediği için sosyoekonomik etkileri büyüktür. Hastaların \%25-50'sinde altta yatan sistemik bir hastalık mevcuttur $(11,12)$.

Üveitler anatomik, etiyolojik ve klinik özelliklerine göre sınıflanabilmektedirler. Klinikte en sık kullanılan anatomik sınıflama olup inflamasyondan etkilenen bölgeye göre ön (iris, siliyer cisim), orta (pars plana bölgesi ve vitreus boşluğu), arka (vitreus, koroid ve retina) ve panüveit (tüm intraoküler dokular) şeklinde isimlendirilmektedir. Arka segmentin tutulduğu durumlarda, tedavi daha güç ve komplekstir. Vakaların \%50'sinde arka segment tutulumu görülmekte ve bu vakaların \%10'u körlükle sonuçlanmaktadır $(11,12)$.

Yakın zamanda, üniversitemizin Göz Hastalıkları Kliniğinin de içerisinde yer aldığı, 33 merkezi içeren 6967 üveitli gözün dâhil edildiği, Türkiye'deki üveitlerin demografik ve klinik özelliklerini yansıtan ilk ulusal kayıt raporu yayınlandı (13). Bu rapora göre; etiyolojik neden olarak \%76,1 oranında non-infeksiyöz, \%15,6 infeksiyöz ve \%8,2 idiyopatik patolojiler yer almaktaydı. Grubun büyük bir bölümünü oluşturan non-infeksiyöz patolojiler arasında 
Behçet Hastalığına bağlı göz tutulumu \%24,9 ile en sık etiyolojik etken olarak ilk sırayı aldığı bildirildi (Şekil-5) (13).

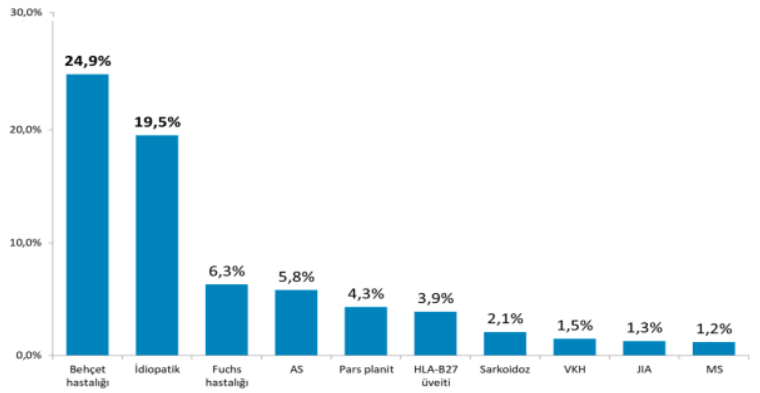

Şekil-5. BÜST çalışma grubunun verilerine göre Türkiye'de non-infeksiyöz üveit etiyolojik nedenleri.

BÜST: Behçet'e bağlı ve Behçet dışı Üveit Sıklığını Tarama, AS: Ankilozan spondilit, VKH: Vogt-Koyanagi- Harada, MS: Multiple skleroz.

\section{Semptom ve Klinik Bulgular:}

Kırmızı göz, akut ön segment inflamasyonunun göstergesi olup, ön üveit olgularında ve ön segment tutulumunun da şiddetli olduğu panüveit olgularında görülmektedir (11). Buradaki hiperemi, konjonktival ve episkleral damarlarda kimyasal mediatörlerin yol açtığı dilatasyona bağlıdır. Hiperemi, perilimbal (siliyer enjeksiyon) veya diffüz olarak prezente olabilir (Şekil-6A) (14).

Kırmızı göz dışında ön segment inflamasyonunda hastaların başlıca şikayetleri ağıı, ışıktan rahatsız olma (fotofobi), ve lakrimasyondur. Akut ön üveitlerde bu semptomlar belirgindir. Ancak sinsi başlangıçı kronik ön üveitlerde ciddi komplikasyonlar gelişene kadar hasta asemptomatik kalabilmektedir. Ağrı, fotofobi ve lakrimasyon trigeminal sinirin irritasyonundan kaynaklanır $(11,14)$.

Ön üveitlerde temel bulgu, inflamasyona bağıı kan-aköz bariyerindeki yıkım nedeniyle ön kamaraya polimorfonukleer lökositler, eritrositler, nekrotik artıkar ve proteinin geçerek reaksiyon oluşturmasıdır. İnflamatuar hücre ve proteinler yoğunluğuna göre ön kamarada serbest bir biçimde veya seviye vermiş bir halde (hipopiyon) görülebilirler (Şekil-6A) (14, 15). Isının etkisi ile ön kamarada aşağıya çöken ve kornea endoteline yapışan inflamatuar hücrelerin oluşturduğu çökeltiler "keratik presipitatlar" olarak adlandırılmaktadır (Şekil-6B). Ön kamara sıvısı içindeki hücre ve proteinler; lens ile iris arasında birikir ve bu iki yapıyı birbirine yapıştırırsa buna "arka sineşi", iris ile korneayı birbirine yapıştırırsa buna da "ön sineşi" adı verilmektedir. İriste atrofi herpetik etiyolojiyi düşündürürken (Şekil-6C), üzerinde küçük nodüller ise granülomatöz reaksiyona işaret etmektedir (Şekil-6D) $(11,14$, 15).

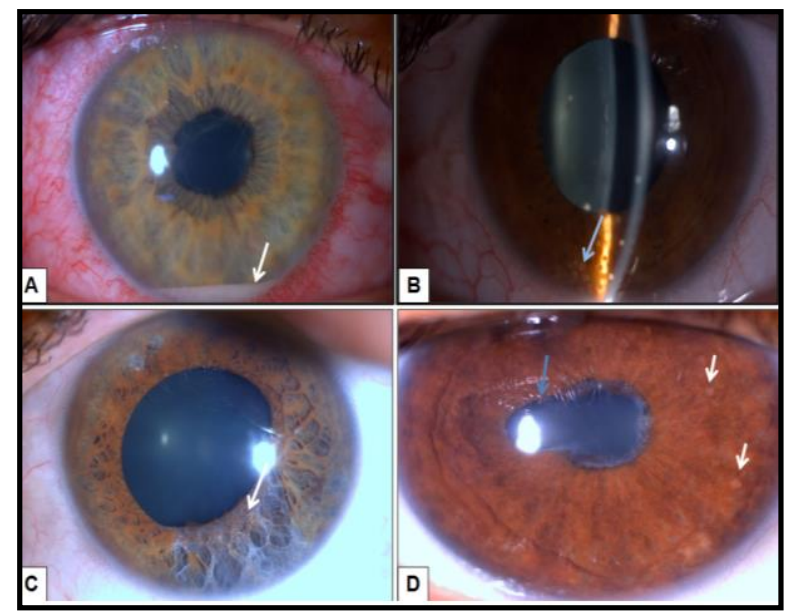

Şekil-6. Ön üveite ait ön segment bulguları. A) Siliyer enjeksiyon ve ön kamarada hipopiyon (ok). B) Slit ışıkile yapılan biomikroskopik bakıda kornea alt yarısında keratik presipitatlar izlenmektedir (ok). C) Herpetik etiyolojiyi düşündüren sektöriyel iris atrofisi (ok). D) Granülomatöz patolojiyi düşündüren iris nodülleri (beyaz ok) ve posterior sineşi (mavi ok) (Üvea Birimi arşivinden).

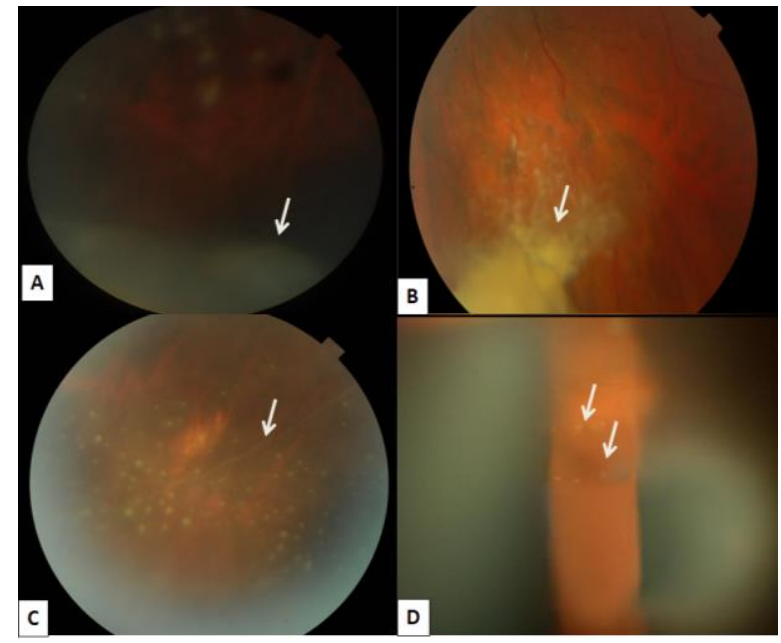

Şekil-7. Orta ve arka üveitte vitreus kondansasyonları.

A) Pars plana bögesinde eksüdasyon (snow banking) (ok). B) Vitreus içinde serbest kolleksiyonlar (ok). C) Pars planitli bir olguda vitreus tabanında çökelmiş punktiform vitreus opasiteleri ve periferik bir vende perivasküler kılıflanma nedeniyle damar duvarında danste artışı (ok). D) Behçet Hastalığı üveitinde lineer dizilim gösteren vitreus incileri (oklar) (Üvea Birimi arşivinden).

Arka segment tutulumunda görme ile ilgili şikayetler ön plandadır. Görme keskinliğinde azalma, uçuşan cisimler (floaters) ve sisli görme şikâyeti sıklıkla mevcuttur. Bu durum vitreusta hücre infiltrasyonu ve protein birikimi nedeniyle 
gelişen opasitelerden kaynaklanmaktadır. Bu vitre kondansasyonları orta üveitte pars plana bölgesinde kartopu opasiteleri (Şekil-7A,B) şeklinde görülürken, bazı infeksiyöz patolojiler ve Behçet Hastalığına bağlı arka üveitte lineer dizilimli ince taneleri şeklinde izlenebilmektedirler (Şekil-7C,D). Yine arka kutupta yer alan beyazsarı renkli retinit/retinokoroidit odakları, makula ödemi veya optik disk inflamasyonu görme kaybına neden olabilirler $(11,15)$.

\section{Ön Üveitler}

Üveit tipleri içinde en sık karşılaşılandır. Tüm üveit olgularının \%28,5-90'ını oluşturmaktadır $(11,14)$. Ön üveitlerin çoğunluğu (\%13,6-52) idiyopatik olarak gelişmektedir (16).

HLA B27 ile ilişkili üveitler ise etiyolojik tanı alan anterior üveitlerin en sık nedenidir. Genellikle 2040 yaştaki erkelerde görülmektedir. Unilateral, akut başlangıçlı, non-granülomatöz özellikte, posterior sineşi ve hipopiyonun eşlik ettiği ön üveit tablosu hakimdir. Olguların yarısında altta sistemik bir hastalık yatmaktadır. Seronegatif spondiloartropatiler (SpA), HLA B27 akut ön üveit ile en kuvvetli ilişkiye sahip sistemik hastalık grubudur. Ankilozan spondilit (AS) bu grubun en sık karşılaşılan hastalığıdır. Ankilozan spondilit hastalarının \%90'ı HLA-B27 pozitifliği gösterir. Hastalık seyrinde $\% 50$ vakada akut ön üveit görülmektedir. Ön üveit ile ilişkili diğer SpA arasında reaktif artrit sendromu, psöriatik artrit ve iltihabi barsak sendromu yer almaktadır (11, 14, 15).

Jüvenil idyopatik artrit (JiA), çocukluk çağı üveitlerine eşlik eden sistemik hastalıklar içerisinde ilk sırayı almaktadır. Kız cinsiyet, pausiartriküler tip ve antinükleer antikor (ANA) pozitifliği üveit gelişimi açısından risk faktörüdür. JiA üveiti daha sessiz ancak kronik seyretme eğilimindedir; band keratopati, katarakt, glokom ve kronik hipotoni gibi komplikasyonlara sıklıkla rastlanır $(11,14)$.

Herpetik ön üveitler, tüm üveitlerin \%5-10'unu, infeksiyöz ön üveitlerin ise en sık nedeni oluşturmaktadır (17). Etken HSV veya VZV olabilmektedir. Keratik presipitatlar yaygın, ince, yıldızımsı veya granülomatöz olabilmektedir. Göz içi basıncında akut $50-60 \mathrm{mmHg}$ ya kadar yükselmemleler görülebilmekte, korneal duyarlılıkta azalama, yama veya sektöriyal tarzda iris atrofileri, pupil distorsiyonu ve translüminasyon defekti görülebilir (Şekil-7C) (14).
Fuchs heterokromik iridosikliti ön üveitlerin \%211 'sinden sorumludur (18). Kronik, hafif bir inflamasyon, karakteristik stellat keratik presipitatlar, iriste heterokromi ve atrofi, katarakt ve daha az sıklıkla glokomun eşlik ettiği üveit şeklidir (15). Genellikle asemptomatik seyirlidir ve kırmızı göze neden olmaz. Ön üveitlerin ayırıcı tanısında akılda tutulmalıdır (11).

\section{Orta Üveitler}

İnflamasyonun başlıca yeri vitreus olup pars plana bölgesinde eksudasyon ve kartopu opasiteleri görülmektedir (Şekil-7A,B). Ayrıca bu tabloya periflebit, optik disk ödemi ve maküla ödemi de eşlik edebilmektedir (Şekil-7C) (15). Multipl skleroz (MS), sarkoidoz, lyme ve tüberküloz orta üveit nedenleri arasında yer almaktadır. Ancak en sık görülen tipi idiyopatik formudur. Pars planit, idiyopatik intermediyer üveitlerin bir alt grubunu teşkil etmektedir. Çocuklarda daha şiddetli seyreder. Sinsi başlangıçlı, gözde ağrı ve kızarıklığa yol açmayan, kronik bir üveit formu olması nedeniyle küçük çocuklar ciddi komplikasyonlar gelişene kadar asemptomatik kalabilen bir hastalıktır (19).

\section{Arka Üveitler}

Arka üveit vitreus, retina, koroid ve optik disk inflamasyonuna verilen genel addır. Görme keskinliğindeki etkilenme lezyonun makulaya yakınlığı ile doğrudan ilişkilidir. Maküler tutulum varlığında görme keskinliği belirgin olarak azalmaktadır. Retinit/koroidit odakları sıklıkla beyaz-sarımtırak renkte yama şeklinde görülmektedir. Aktif lezyonların sınırları silik olup üzerinde eksudasyon ve komşu vitreusta hücre bulunur. Lezyonlar inaktif hale geldikçe sınırları belirginleşir, beyaz görünüme sahip atrofik alanlar olarak görülür. Retinit odakları kabarık üzeri bulanık beyaz, sarı renkte bir görünüme sahiptir (15).

Vaskülitik patolojilerde, retinal inflamasyon özellikle damar duvarı çevresinde segmenter veya diffüz beyaz bulanık kılıf şeklinde görülmektedir (Şekil-8). İnflamasyonun gerilemesi ile damar duvarı boyunca beyaz parlak çizgilenme şeklinde sekel bulgu izlenmektedir (19). Venlerdeki inflamasyon periflebit, arteriollerdeki inflamasyon ise periarterit olarak adlandırılır. Periflebite neden olan durumlar Behçet Hastalığı, tüberküloz, sarkoidoz, MS ve pars planittir. Periarterit yapan başlıca hastalıklar arasında ise yine Behçet Hastalığı, SLE, PAN, 
granülomatozisli polianjiti, Churg-Strauss sendromu, Crohn, Susac sendromu, kedi tırmığı ve oküler toksoplazmozis sayılabilir (20). Inflamasyona sekonder gelişen retinal ven tıkanıklıklarında (okluzif vaskülit), ilgili kadranda retinal ödem ve hemorajiler oluşmaktadır. Arter tıkanıklığında ise iskemik retinal ödemi gelişmektedir. Tıkanmış damarlar, ileri dönemde içinde akım olmayan beyaz kordonlar (hayalet damarlar) şeklinde görülmektedirler. Şiddetli arka üveitlerde inflame koroid veya geçirgenliği artmış retinal damarlardan ekstravaze olan seruma sekonder eksudatif retina dekolmanı gelişebilmektedir. Optik disk ödem ve hiperemisi genellikle arka üveitlere eşlik etmektedir (19).

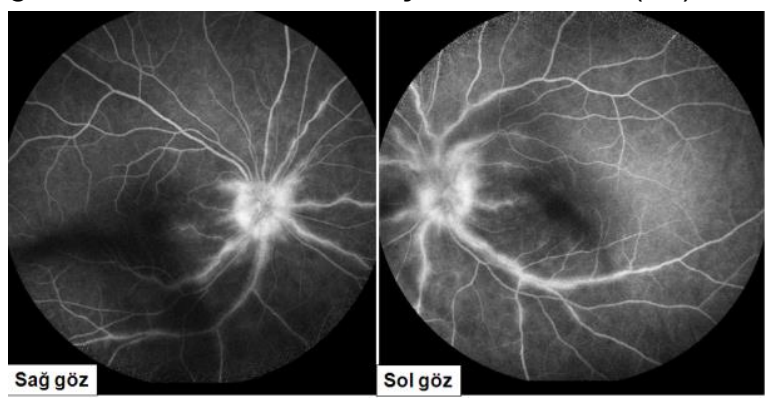

Şekil-8. Retinal vaskülitte floresein anjiografi bulguları.

Retinal vaskülitli bir olgunun floresein anjiografisinde; optik disklerde ve çevresindeki vasküler yapıların duvarlarında yoğun boyanma (Retina Birimi arşivinden).

\section{Panüveitler}

Ön kamara, retina ve koroidin tutumu mevcuttur. Non-infeksiyöz panüveit etkenleri Behçet Hastalığı, sarkoidoz, Vogt-Koyanagi-Harada ve sempatik oftalmidir. İnfeksiyöz etkenlerden en sık tüberküloz, toksoplazmozis ve sifiliz panüveite neden olurlar (11).

Behçet Hastalığı, alevlenme ve remisyonlar ile seyreden kronik, multisistemik otoimmün bir hastalıktır (21). Japonya'dan Türkiye'ye kadar tarihi İpekyolu üzerindeki ülkelerde sık görülen bu hastalık, ülkemizde 20-420/100.000 arasında bildirilen oranı ile dünya üzerindeki en yüksek prevalansa sahiptir (22). Ülkemizde noninfeksiyöz üveitlerin en sık etkenidir (13).

Oküler tutulum, Behçet Hastalığının en ciddi organ tutulumlarından biridir. Hastaların \%70'inde göz tutulumu görülür ve bu hastaların $\% 68$ kadarı erkektir. Oküler tutulum, \%10-20 hastada ilk bulgu olarak ortaya çıkmakla birlikte çoğu hastada oral aft gibi başlangıç bulgularından itibaren 2-4 yıl içerisinde görülmektedir. Klasik oküler tutulum, bilateral non-granülomatöz panüveit ve retinal vaskülit şeklindedir. Genellikle ilk ataklar tek taraflı ve ön üveit şeklinde ortaya çıkarken, tekrarlayan ataklarda hastalık çift taraflı ve arka segment tutulumu yapma eğilimindedir (22). BH'nda izlenen vaskülit, hem arterleri, hem de venleri etkileyen tıkayıcı, nekrotizan özelliktedir. Tıkayıcı vaskülit akut periflebit veya tromboanjitis obliterans şeklinde olabilir. Anjiografik olarak "eğrelti otu" görünümünde diffüz kapiller kaçak, Behçet'e bağlı retinal vaskülitin tipik özelliğidir (Şekil-9). Venlerdeki kılıflanma arterlerden önce başlamaktadır. Periflebit ilerleyip tromboanjitis obliterans şekline dönüştüğünde retinada ödem ve eksudalar oluşmaktadır. Santral retinal ven/arter oklüzyonu ve sinir lifi tabakası infarktları kalıcı görme kaybına yol açabilmektedir $(23,24)$.

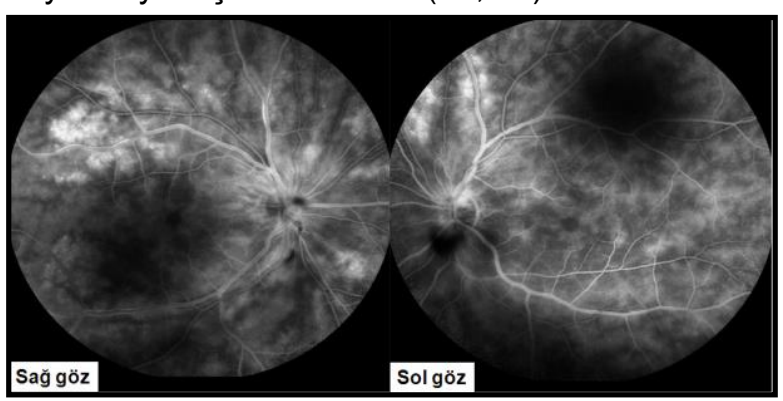

Şekil-9. Behçet hastalığına bağlı arka segment tutulumunda floresein anjiografi bulguları.

Behçet Hastalığına bağlı arka segment tutulumu olan bir hastanın Floresein Anjiografisinde arka kutupta tüm vasküler yapılardan "eğrelti otu şeklinde diffüz kapiller kaçak (Retina Birimi arşivinden).

Sarkoidoz, adrenal bezler dışında tüm organları tutan multisistemik, non-kazeifiye granülomatöz bir hastalıktır. Hastalık her yaşta görülebilmekle birlikte 20-50 yaştaki kadınlarda daha fazla ortaya çıkma eğilimindedir. Göz tutulumu \%25-50 oranında bildirilmiş olup çoğu vakada (\%93) tutulum bilateral olmaktadır. En sık göz bulguları üveit (\%30-70) ve konjonktival nodüller (\%40) şeklinde görülmektedir. Hastaların \%85'inde kronik granülomatöz ön üveit (koyun yağı keratik presipitatlar, iris nodülleri), \%25'inde ise arka arka segment tutulumu (klasik mum damlacıkları, perivenöz kılıflanma, Dalen-Fuchs nodülleri) vardır (25).

\section{Tedavi:}

Üveit tedavisindeki amaç gözdeki inflamasyonu baskılayarak ağrıyı azaltmak, tutulan bölgelerdeki hasarı önlemek ve rekürrensi engellemektir. Sistemik ve topikal steroidli preparatlar tedavinin 
ana unsurunu oluştururlar. Ön üveitlerde topikal damla formunda kullanım çoğunlukla yeterli olurken, arka üveitlerde sistemik tedavi gerekmektedir. Sikloplejik damlalar ile ön üveitlerde pupil dilatasyonu sağlanarak arka sineşi gelişimi önlenebilir ve siliyer spazma bağlı ağrı azaltılabilir. İnfeksiyöz etiyolojili olgularda etkene yönelik uygun antibiyotikler, antiviral ve anitparaziter ajanlar kullanılmalıdır. Behçet Hastalığı gibi otoimmün hastalıklarda hastalık rekürrensini önlemek ve kronik steroid kullanımından kaçınmak amacıyla mutlaka immünsüpresif ilaçlar (MTX, mikofenolat mofetil, azatiopirin, sandimmun vs.) veya biyolojik ajanlar (interferon, anti-TNF) başlanmalıdır $(15,19)$.

\section{Sonuç}

Akut kırmızı göze neden olan sklerit ve üveitlerin önemli bir kısmında altta sistemik bir hastalığın yatması nedeniyle, doğru teşhis ve etkin bir tedavi için göz hekimlerinin yanında romotologların da dahil olduğu multidisipliner yaklaşım gereklidir.

\section{Kaynaklar}

1. Gilani CJ, Yang A, Yonkers M. Differentiating urgent and emergent causes of acute red eye for the emergency physician. West J Emerg Med 2017; 18 (3): 509-17.

2. Whitcup SM. Scleritis. In: Nussenblatt RB and Whitcup SM (eds), Uveitis: Fundamentals and Clinical Practice 4th Edition, St. Louis: Mosby, 2010; 264-8.

3. Sainz de la Maza M, Foster CS, Jabbur NS. Scleritis-associated uveitis. Ophthalmology 1997; 104 (1): 58-63.

4. Kanski JJ. Episklera ve Sklera. In:Nischal K and Pearson A (eds). Klinik Oftalmoloji: Sistematik Yaklaşım 7th Editation. Edinburgh: Elsevier, Saunders, 2013; 252-67.

5. Kadayıfçılar S. Episklerit ve Sklerit. In: Aydın P and Aydın Akova Y (eds), Temel Göz Hastalıkları. 1.basım, Ankara: Güneş Kitabevi, 2001; 83-187.

6. Dönmez O, Aydın Akova Y. Noninfeksiyöz Skleritlerde Güncel Tanı ve Tedavi. Tuğal Tutkun I, editör. Üveit Tanı ve Tedavisinde Güncel Yaklaşımlar. 1. Baskı. Ankara: Türkiye Klinikleri; 2019;23-31.

7. Watson PG, Hayreh SS. Scleritis and episclerits. Br J Ophthalmol 1976; 60: 163-91.

8. Budak K, Günalp İ. Skleritler ve Episkleritler. T Klin Oftalmoloji 1994;3: 62-70.

9. Agrawal R, Lavric A, Restori M, Pavesio C, Sagoo MS. Nodular Posterior Scleritis: Clinico-Sonographic Characteristics and Proposed Diagnostic Criteria. Retina. 2016; 36 (2): 392-40.

10. Kumar A, Ghose A, Biswas J, Majumder PD. Clinical profile of patients with posterior scleritis: A report from Eastern India. Indian J Ophthalmol 2018; 66 (8): 1109-12.

11. Sızmaz S. Kırmızı Göz Nedenleri-Üveitler. Turk J Ophthalmol 2012; 42: 57-62.

12. Suttorp-Schulten MS, Rothova A. The Possible Impact of Uveitis in Blindness: A Literature Survey. Br J Ophthalmol 1996;80(9): 844-8.

13. Yalçındağ FN, Özdal PC, Özyazgan Y, Batıoglu F, Tugal-Tutkun I; BUST Study Group. Demographic and Clinical Characteristics of Uveitis in Turkey: The First National Registry Report. Ocul Immunol Inflamm 2018 (26): 17-26.

14. Çakar Özdal P. Ön Üveitler. Turkiye Klinikleri J Ophthalmol-Special Topics 2008;1:27-37.

15. Çakmak H, Erkan E. Üveitler. JCAM 2015;115-8.

16. Sengün A, Karadağ R, Karakurt A, Saricaoğlu MS, Abdik O, Hasiripi H. Causes of uveitis in a referral hospital in Ankara, Turkey. Ocul Immunol Inflamm 2005; 13: 45-50.

17. Siverio Jr CD, Imai Y, Cunningham ET. Diagnosis and management of herpetic anterior uveitis. Int Ophthalmol Clin 2002; 42: 43-8.

18. Birnbaum AD, Tessler $\mathrm{HH}$, Schultz $\mathrm{KL}$, et al. Epidemiologic relationship between fuchs heterochromic iridocyclitis and the United States rubella vaccination program. Am J Ophthalmol 2007; 144: 424-8.

19. Tuğal Tutkun İ. Üveitlere genel bakış. Klinik Gelişim 2012; (25): 26-34.

20. Erol N. Retinal Vaskülitler. Türkiye Klinikleri J Ophthalmol-Special Topics 2011; 4 (3): 115-22.

21. Güven Yılmaz S, Yüce B, Ateş H. Behçet Hastalığı'nda klinik bulgular, klinik tanı ve sınıflandırma. Güncel Retina 2018; 2 (4): 329-3. 
22. Idil A, Gürler A, Boyvat A, et al. The prevalence of Behçet's disease above the age of 10 years. The results of a pilot study conducted at the Park Primary Health Care Center in Ankara, Turkey. Ophthalmic Epidemiol 2002; 9: 325-31.

23. Şengün A. Behçet Hastalığı. In: Akbatur HH, Şengün A (eds). Behçet Hastalığı, Endoftalmiler ve Üveitler. Atlas Kitapçılık Tic.Ltd.Şti, Ankara, 2002; 79-105.

24. Tuğal Tutkun İ. Behçet Hastalığı. Turkiye Klinikleri J Ophthalmol-Special Topics 2008; 1: 44-50.

25. Mirza GE. Sarkoidoz, Sempatik Oftalmi, Vogt-Koyanagi- Harada Sendromu. Turkiye Klinikleri J OphthalmolSpecial Topics 2008; 1: 51-61. 